\title{
Artikel
}

\section{De ontwikkeling en implicaties van kinder- en mensenrechten op het gebied van klimaatverandering}

\author{
Dr. M.J. Wewerinke-Singh, mr. J.A.M. Stein MSc en prof. mr. J.E. Doek*
}

\section{Inleiding}

De eens omstreden (antropogene) klimaatverandering kan niet meer worden ontkend: het VN-klimaatpanel (Intergovernmental Panel on Climate Change) heeft in zijn rapporten herhaaldelijk geconcludeerd dat klimaatverandering 'ondubbelzinnig' is en dat deze voornamelijk wordt veroorzaakt door menselijke activiteiten. ${ }^{1}$ Wetenschappelijke tijdschriften staan vol met artikelen over de schadelijke en mogelijk catastrofale gevolgen van klimaatverandering. Zo kan het desastreuze gevolgen voor de menselijke gezondheid hebben en zelfs mensenlevens kosten. Door stijgende temperaturen krijgen luchtwegproblemen, allergieën en infectieziekten bijvoorbeeld makkelijker een kans, zeker in combinatie met luchtvervuiling (die net als klimaatverandering het gevolg is van de verbranding van fossiele brandstoffen). Het KNMI waarschuwde onlangs dat bij ongewijzigd

* Dr. M.J. Wewerinke-Singh is als universitair docent verbonden aan het Grotius Centre for International Legal Studies in Leiden. Mr. J.A.M. Stein is lid van de werkgroep Jeugd- en Gezondheidsrecht van het Nederlands Juristen Comité voor de Mensenrechten (NJCM). Dit artikel vloeit voort uit de door het NJCM georganiseerde seminar 'Kinderrechten \& klimaat' gehouden in februari 2020 te Den Haag. Prof. mr. J.E. Doek is Emeritus hoogleraar familie en jeugdrecht bij de VU Amsterdam en gastmedewerker bij de afdeling jeugdrecht van de Universiteit Leiden.

1. Intergovernmental Panel on Climate Change (2013), 'Summary for Policymakers', in: T.F. Stocker e.a., Climate Change 2013: The Physical Science Basis. Contribution of Working Group I to the Fifth Assessment Report of the Intergovernmental Panel on Climate Change, Cambridge: Cambridge University Press. beleid de kritische grens van anderhalve graad wereldwijde opwarming mogelijk al over negen jaar wordt bereikt. $^{2}$ Het veranderende klimaat leidt tevens tot een stijgende zeespiegel, toenames van stormen, extreme hittegolven, zware regenval, voedselonzekerheid en gedwongen migratie, wellicht in de toekomst ook voor Nederlanders. ${ }^{3}$

In toenemende mate prominent in de klimaatdiscussie zijn kinderen en hun rechten op dit vlak. Hierbij staat centraal dat kinderen door klimaatverandering disproportioneel geraakt worden. Zo kunnen zij door hun minder ontwikkelde fysiologie en immuunsysteem eerder gezondheidsproblemen krijgen dan gezonde volwassenen. De Wereldgezondheidsorganisatie schat dat van de 5,9 miljoen overleden kinderen onder de 5 jaar een kwart voorkomen had kunnen worden door de vermindering van milieurisico's. ${ }^{4}$ Bovendien zullen kinderen in de toekomst moeten leven met de gevolgen van beslissingen die vandaag door volwassenen worden genomen. De recente bevinding dat $69 \%$ van de jongeren onder de 18 jaar klimaatverandering ziet als een

2. NOS (2021), 'KNMI: 1,5 graad opwarming mogelijk al over negen jaar bereikt', https://nos.nl/artikel/2371217-knmi-1-5-graad-opwarmingmogelijk-al-over-negen-jaar-bereikt.html.

3. V. Masson-Delmotte, e.a. (2018), 'Global Warming of $1.5^{\circ} \mathrm{C}$ : An IPCC Special Report on the Impacts of Global Warming of $1.5^{\circ} \mathrm{C}$ above Pre-Industrial Levels and Related Global Greenhouse Gas Emission Pathways, in the Context of Strenghtening the Global Response to the Threat of Climate Change'; R. Bregman (2020), 'Een brief aan alle Nederlanders: Klimaatverandering bedreigt het voortbestaan van ons land', https://decorrespondent.nl/10813/een-brief-aan-alle-neder landers-klimaatverandering-bedreigt-het-voortbestaan-van-ons-land/ 3225544326972-9c9aa0a2?pk_campaign=proefmail\&pk_kwd=10beste van2020-redactie.

4. WHO (2017), 'Don't pollute my future! The impact of the environment on children's health' (Geneva), p. 1. 
noodsituatie, is dan ook niet verwonderlijk. ${ }^{5}$ Positief is daarom dat mensen- en kinderrechten de afgelopen vijftien jaar een steeds belangrijkere rol zijn gaan spelen in klimaatbeleid en dat hiervoor in toenemende mate aandacht is door middel van verdragen, resoluties, (gerechtelijke) beslissingen en rapporten. ${ }^{6}$

Dit artikel tracht aan deze lijn bij te dragen door in te gaan op de juridische implicaties van klimaatverandering vanuit het kind bezien; in hoeverre hebben kinderen klimaatgerelateerde rechten en hoe kunnen zij deze gerechtelijk effectueren? Eerst zal worden ingegaan op internationale ontwikkelingen omtrent klimaatverandering binnen het mensenrechtenkader, gevolgd door een analyse van het internationaal kinderrechtenkader onder het Internationaal Verdrag inzake de Rechten van het Kind (IVRK) en de toepasbaarheid van dit kader op klimaatverandering. Tot slot zal worden ingegaan op het klachtrecht onder het IVRK naar aanleiding van een recente klacht over klimaatverandering die is ingediend bij het $\mathrm{VN}$-Comité inzake de Rechten van het Kind (hierna ook: VN-Kinderrechtencomité) en hoe kinderen in Nederland hun rechten op dit vlak kunnen effectueren, gevolgd door een concluderende beschouwing.

\section{Mensenrechten ${ }^{7}$}

Hoewel het belang van mensenrechten voor milieubescherming en ontwikkeling al sinds enkele decennia erkend is ${ }^{8}$ speelden mensenrechten tot enkele jaren geleden nauwelijks een rol in klimaatdebatten. ${ }^{9}$ De tekst van het Raamwerkverdrag van de VN inzake klimaatverandering refereert niet aan mensenrechten en ook in de regels en richtlijnen voor de uitvoering van het Raamwerkverdrag en het Kyoto-protocol ontbreken referenties aan mensenrechtenstandaarden of -verplichtingen. Deze situatie is veranderd: in de preambule van de Overeenkomst van Parijs worden Partijen opgeroepen om hun respectievelijke verplichtingen betreffende mensenrechten te eerbiedigen, te bevorderen en in aanmerking te nemen bij hun optreden om klimaatverandering tegen te gaan. ${ }^{10}$ Deze referentie naar mensenrechten reflecteert een bredere trend van inter-

5. UNDP (2021), Peoples' Climate Vote, UNDP \& University of Oxford, p. 56.

6. S. Atapattu, Human Rights Approaches to Climate Change: Challenges and Opportunities (Routledge 2016); S. Duyck, S. Jodoin, and A. Johl, The Routledge Handbook of Human Rights and Climate Governance (Routledge 2018)

7. Deze paragraaf is deels gebaseerd op S. Jodoin, A. Savaresi \& M. Wewerinke-Singh (2020), 'Rights-Based Approaches to Climate Decision-Making' (ongepubliceerd paper).

8. W.A. Shutkin, (1990) 'International Human Rights Law and the Earth The Protection of Indigenous Peoples and the Environment', Virginia Journal of International Law 31, p. 479; M. Fitzmaurice, (2004), 'Linking Human Rights and Environment', in: Journal of Environmental Law 16, p. 411.

9. J.H. Knox, (2009), 'Climate Change and Human Rights Law', Virginia Journal of International Law 1, p. 3.

10. UNFCCC, Paris Agreement (adopted 12 December 2015) UN Doc FCCC/CP/2015/L.9/Rev/1, preambule. nationale erkenning van de link tussen klimaatverandering en mensenrechten.

\section{Klimaatverandering, de VN-Mensenrechtenraad}

en VN-verdragsorganen voor mensenrechten

Als gevolg van de voorlichtings- en pleitbezorgingsactiviteiten van inheemse volkeren, kleine eilandstaten en klimaatactivisten is de relevantie van mensenrechten voor het omgaan met klimaatverandering inmiddels in brede kring erkend. ${ }^{11}$ In 2005 dienden inheemse Inuit gemeenschappen uit het Noordpoolgebied een petitie in bij de Inter-Amerikaanse Commissie voor Mensenrenrechten, waarin betoogd werd dat de bijdragen van de Verenigde Staten aan klimaatverandering hun recht op leven, veiligheid, gezondheid, cultuur, eigendom, traditioneel grondgebied, levensonderhoud en behuizing schond. Hoewel de petitie werd afgewezen, droeg het initiatief bij an het begrijpen van klimaatverandering als een probleem waardoor gemarginaliseerde groepen disproportioneel geraakt worden, en dat vereist dat grote vervuilers aansprakelijk gesteld worden voor hun bijdragen aan het probleem. ${ }^{12}$ De petitie inspireerde ook leiders van kleine eilandstaten om klimaatverandering op de agenda van de $\mathrm{VN}-$ Mensenrechtenraad (hierna: de Raad) te zetten. ${ }^{13}$

In 2008 nam de Raad de eerste resolutie aan over mensenrechten en klimaatverandering, die erkende dat klimaatverandering 'een onmiddellijke en verregaande bedreiging vormt voor volkeren en gemeenschappen over de hele wereld en gevolgen heeft voor de volledige eerbiediging van mensenrechten'. ${ }^{14}$ Inmiddels heeft de Raad in totaal tien resoluties over klimaatverandering angenomen, waarin onder andere de disproportionele gevolgen voor kinderen worden erkend. ${ }^{15}$ Op verzoek van de Raad hebben het Bureau van de Hoge Commissaris van de VN voor de Rechten van de Mens (OHCHR) en de speciale rapporteurs van de Raad een reeks van onderzoeken, rapporten en verklaringen opgesteld over verschillende thema's gerelateerd aan klimaatverandering en mensenrechten. ${ }^{16}$ Een van deze rapporten, opgesteld door OHCHR, behandelt specifiek

11. A. Schapper en M. Lederer, (2014), 'Introduction: Human Rights and Climate Change: Mapping Institutional Inter-Linkages', Cambridge Review of International Affairs 27, p. 666; Duyck, Jodoin en Johl (No. 4).

12. S. Jodoin, S. Snow \& A. Corobow (2020), 'Realizing the Right to Be Cold? Framing Processes and Outcomes Associated with the Inuit Petition on Human Rights and Global Warming', Law and Society Review 54, p. 168.

13. Small Island Developing States, Malé Declaration on the Human Dimension of Global Climate Change (2007).

14. UN Human Rights Council, Resolution 7/23, adopted at the HRC's 41st meeting on 28 March 2008.

15. Office of the United Nations High Commissioner for Human Rights, 'Human Rights Council Resolutions on Human Rights and Climate Change', www.ohchr.org/EN/Issues/HRAndClimateChange/Pages/ Resolutions.aspx.

16. Office of the United Nations High Commissioner for Human Rights, 'OHCHR and Climate Change', www.ohchr.org/en/issues/ hrandclimatechange/pages/hrclimatechangeindex.aspx. 
de relatie tussen klimaatverandering en de rechten van het kind. ${ }^{17}$

VN-verdragsorganen voor mensenrechten hebben ook de verplichtingen van staten met betrekking tot klimaatverandering verduidelijkt in hun gezaghebbende richtsnoeren en toezicht op de naleving door lidstaten. ${ }^{18}$ Regionale mensenrechtenorganen hebben eveneens klimaatverandering behandeld als onderdeel van hun bestaande agenda's. ${ }^{19}$

\section{Rechtszaken over mensenrechten en klimaatverandering}

Ten slotte is er een toenemend aantal rechtszaken waarin het belang van mensenrechten voor het aanpakken van klimaatverandering centraal staat. ${ }^{20}$ Een van de eerste zaken was Stichting Urgenda v. Staat der Nederlanden, die leidde tot een uitspraak van de Hoge Raad waarin de staat aansprakelijk gesteld wordt voor onvoldoende ambitieus klimaatbeleid op grond van het Europees Verdrag tot bescherming van de Rechten van de Mens en de fundamentele vrijheden (EVRM). ${ }^{21}$ Ook in Leghari v. Federation of Pakistan en Demanda Generaciones Futuras v. Minambiente (Colombia) concludeerden nationale rechtbanken dat inadequaat klimaatbeleid een schending vormde van de mensenrechtenverplichtingen van de staat. De rechtbanken in deze zaken gelasten de staat dan ook om specifieke maatregelen te treffen om de schadelijke effecten van klimaatverandering in te perken, namelijk door het oprichten van een Klimaatcommissie (Leghari), ${ }^{22}$ het uitvoeren van maatregelen om ontbossing tegen te gaan (Generaciones Futuras) ${ }^{23}$ en het aannemen van een ambitieuzere doelstelling voor mitigatie van klimaatverandering (Urgenda). Deze zaken bevestigen dat mensenrechtenverplichtingen van toepassing zijn op besluitvorming omtrent klimaatverandering en laten zien dat inadequaat klimaatbeleid juridische gevolgen heeft.

Klimaatzaken gebaseerd op mensenrechten zijn eveneens aangespannen in Australië, Oostenrijk, België, Canada, Frankrijk, Duitsland, India, Ierland, Italië, Pakistan, Noorwegen, de Verenigde Staten, Zweden,

17. UN General Assembly, 'Analytical Study on the Relationship between Climate Change and the Full and Effective Enjoyment of the Rights of the Child. Report of the Office of the United Nations High Commissioner for Human Rights', UN Doc. A/HRC/35/13 (4 May 2017).

18. United Nations Human Rights Council (UNHRC), 'Report of the Independent Expert on the Issue of Human Rights Obligations Relating to the Enjoyment of a Safe, Clean, Healthy and Sustainable Environment, John H. Knox: Mapping Report' (2013); Committee on the Elimination of Discrimination Against Women and others, 'Joint Statement on "Human Rights and Climate Change"' (2019).

19. S. Atapattu, (2018), 'Climate Change under Regional Human Rights Systems' in: S. Duyck, S. Jodoin \& A. Johl (eds), Routledge Handbook of Human Rights and Climate Governance, New York: Routledge.

20. Peel en Osofsky (n 2); A. Savaresi \& J. Auz (2019), 'Climate Change Litigation and Human Rights: Pushing the Boundaries' Climate Law 9, p. 244.

21. The State of the Netherlands v. Urgenda Foundation, (20 December 2019) case 19/00135.

22. Lahore High Court, Ashgar Leghari c Federation of Pakistan, et al. (2015).

23. Corte Suprema de Justicia R de C, Demanda Generaciones Futuras v. Minambiente (2018).
Zwitserland, Zuid Afrika en Zuid Korea, en voor regionale hoven en internationale verdragsorganen. ${ }^{24}$ Een aantal van deze zaken, waaronder een klacht die is ingediend bij het VN-Kinderrechtencomité, richt zich specifiek op vermeende schendingen van de rechten van het kind gerelateerd aan klimaatverandering. ${ }^{25}$ Deze klacht bespreken we later in dit artikel.

\section{Kinderrechten \& klimaat}

Het IVRK - door 196 landen geratificeerd - is het belangrijkste instrument om na te gaan of en zo ja welke kinderrechten van belang zijn voor de bestrijding van klimaatverandering. Hoewel in het IVRK een enkele verwijzing naar de natuurlijke omgeving en het milieu te vinden is, ontbreekt een daadwerkelijk 'klimaatrecht' in het verdrag. ${ }^{26}$ Dit is niet verwonderlijk, aangezien klimaatdebatten geen noemenswaardige rol speelden tijdens het opstellen van het IVRK (1978-1989). ${ }^{27}$ Desondanks valt klimaatverandering wel degelijk onder het bereik van het IVRK, omdat die verandering werkelijk ieder recht in het IVRK - in meer of mindere mate kan raken. ${ }^{28}$

Het is tegen deze achtergrond dat ook het VN-Kinderrechtencomité in toenemende mate aandacht besteedt aan klimaatverandering, bijvoorbeeld door middel van een 'Day of General Discussion' (2016) en in de 'General Comments'29 en 'Concluding Observations' ${ }^{30}$ Werd in 2015 door het Comité volgens Arts in slechts 4 van de 24 'Concluding Observations' aandacht besteed aan dit onderwerp, ${ }^{31}$ in 2019 betrof dit 10 van de 17, met

24. Dit betreft zaken waarbij aanklagers of juridische of quasi-juridische organen expliciet refereren aan zowel klimaatverandering als mensenrechten in hun juridische argumentatie. Zie de 'Climate Change Litigation Databases', Sabin Center for Climate Change Law, www.climatecasechart.com.

25. Zie bijv. Juliana v. United States, 947 F 3d 1159, 32 (9th Cir 2020); La Rose v. Her Majesty the Queen, 2020 FC 1008; Pandey v. India, No 187/2017, Decision rendered by the Green Tribunal Principal Bench, New Delhi (15.01.2019); Ali v. Federation of Pakistan, filed in January 2016 at the Supreme Court of Pakistan; Mbabazi and Others v. The Attorney General and National Environmental Management Authority, Civil Suit No. 283 of 2012. Zie ook N. Rogers (2020), 'Victim, litigant, activist, messiah: the child in time of climate change', Journal of Human Rights and the Environment 11, p. 103.

26. Vgl. de preambule, art. 24(2)(c) en 29(1)(e) IVRK.

27. UNHRC, Legislative History of the Convention on the Rights of the Child, HR/PUB/07/1, New York \& Geneva: UN.

28. Vgl. UNHRC (2017), Analytical study on the relationship between climate change and the full and effective enjoyment of the rights of the child, A/HRC/35/13, par. 29.

29. Een document met een nadere uitleg van een of meer artikelen van het IVRK. Zie ook J.E. Doek, 'General Comments van het VN Comité voor de rechten van het kind: betekenis in de praktijk' in: M.R. Bruning, K.F.M. Klep \& E C.C. Punselie (red.), De invloed van 30 jaar Kinderrechtenverdrag in Nederland. Perspectieven voor de rechtspraktijk, p. 15-25. Deventer: Wolters Kluwer 2020.

30. Aanbevelingen van het $\mathrm{VN}$-Kinderrechtencomité aan een verdragsstaat.

31. K. Arts, (2019), 'Children's Rights and Climate Change', in: C. FentonGlynn (ed), Children's Rights and Sustainable Development: Interpreting the UNCRC for Future Generations, Cambridge: Cambridge University Press, 2019, p. 216-235 
daarbij uitgebreidere overwegingen dan voorheen. ${ }^{32}$ In veel van deze gevallen is nu zelfs een aparte paragraaf gewijd aan het onderwerp klimaatverandering, waarbij verder niet altijd duidelijk is onder welk recht uit het IVRK het probleem wordt geschaard (vaak staat het onder de gezamenlijke noemer 'Disability, basic health and welfare'). Op basis van het IVRK, gecombineerd met deze aanvullende uitleg, volgt hierna een uiteenzetting van de belangrijkste aan klimaat gerelateerde kinderrechten.

\section{Artikel 24 IVRK: het recht op gezondheid}

Het recht dat momenteel het duidelijkst in verband wordt gebracht met klimaat is vastgelegd in artikel 24 IVRK dat - onder andere - het recht van het kind op het genot van 'de grootst mogelijke mate van' gezondheid bevat. Dit recht ziet niet alleen op een goede gezondheidszorg, maar ook op de onderliggende factoren die de gezondheid van een kind bepalen. Hierbij verwijst het tweede lid onder meer naar de gevaren en risico's van milieuverontreiniging. Door de jaren heen heeft het VN-Kinderrechtencomité hierin een stap verder genomen door in 2013 bij de uitleg van artikel 24 IVRK expliciet te noemen dat de relevantie van milieu voor de gezondheid van kinderen verder gaat dan milieuverontreiniging alleen. ${ }^{33}$ Het Comité benoemt klimaatverandering in dit kader bovendien als een van de grootste bedreigingen voor de gezondheid van kinderen, hetgeen dient te worden aangepakt. ${ }^{34}$

Ook in de Concluding Observations is inmiddels een sterke link te vinden tussen het recht op gezondheid en klimaatverandering. Hoewel - zoals genoemd - de overwegingen van het Comité ten aanzien van klimaat gerelateerde zaken onder een afzonderlijke noemer worden vermeld, wordt in een groot deel van de geuite zorgen en aanbevelingen een link gelegd tussen klimaat en gezondheid. Zo wordt in de bestudeerde Concluding Observations uit 2019 het negatieve effect van klimaatverandering op het recht op gezondheid meermaals benadrukt. ${ }^{35}$ Ook werd diverse lidstaten verzocht onderzoek te doen naar de luchtvervuiling in hun land, de gevolgen hiervan voor de gezondheid van kinderen in kaart te brengen en maatregelen te nemen die deze impact verminderen. ${ }^{36}$ Australië werd zelfs verzocht de huidige klimaatmaatregelen te versnellen, onder andere

32. VN-Kinderrechtencomité (2019), Concluding observations on: Australia, CRC/C/AUS/CO/5-6; Belgium, CRC/C/BEL/CO/5-6; Cabo Verde, $\mathrm{CRC} / \mathrm{C} / \mathrm{CPV} / \mathrm{CO} / 2$; Guinea, CRC/C/GIN/CO/3-6; Japan, CRC/C/ JPN/CO/4-5; Malta, CRC/C/MLT/CO/3-6; Mozambique, CRC/C/ MOZ/CO/3-4; Singapore, CRC/C/SGP/CO/4-5; Tonga, CRC/C/ TON/CO/1; Bosnia and Herzegovina, CRC/C/BIH/CO/5-6.

33. VN-Kinderrechtencomité (2013), General Comment No. 15 on The right of the child to the enjoyment of the highest attainable standard of health (article 24), CRC/C/GC/15, par. 50

34. VN-Kinderrechtencomité (2013), General Comment No. 15 on The right of the child to the enjoyment of the highest attainable standard of health (article 24), CRC/C/GC/15, par. 50

35. Zie bijv. VN-Kinderrechtencomité (2019), Concluding observations on: Australia, CRC/C/AUS/CO/5-6, par. 40; Belgium, CRC/C/BEL/CO/5-6, par. 35.

36. VN-Kinderrechtencomité (2019), Concluding observations on: Belgium, CRC/C/BEL/CO/5-6, par. 35; Malta, CRC/C/MLT/CO/3-6, par. 37; Bosnia and Herzegovina, CRC/C/BIH/CO/5-6, par. 36 door targets en deadlines te stellen voor de uitfasering van kolen en om in $100 \%$ van de elektriciteitsbehoefte te voorzien met hernieuwbare energie. ${ }^{37}$ Dit laat zien dat ook de aanbevelingen op dit vlak steeds specifieker worden.

De aanbevelingen zijn een verdere uitwerking van hetgeen reeds in de General Comments is vervat. Hieruit volgt dat verdragsstaten alle geschikte juridische, administratieve en andere maatregelen dienen te treffen om een schending van het recht op gezondheid te voorkomen (vgl. art. 4 IVRK). Hierbij is het aan de verdragsstaat om aan te tonen dat het alle maximaal beschikbare middelen heeft ingezet voor de realisatie hiervan. ${ }^{38}$ Maatregelen die de realisatie van het recht op gezondheid in de weg staan, mogen onder geen enkele omstandigheid genomen worden, ook niet in tijden van een economische crisis. ${ }^{39}$ Concreet gezien vraagt artikel 4 IVRK daarmee onder andere om maatregelen ter bewerkstelling van schoon drinkwater, effectief afvalbeheer en de aanpak van milieuverontreiniging. ${ }^{40}$

Verdragsstaten dienen daarnaast niet-overheidsinstanties bewust te maken van hun verantwoordelijkheden, waarbij met name bedrijven het recht van het kind op gezondheid dienen te respecteren en de negatieve impact op dit recht van het kind als gevolg van hun activiteiten moeten voorkomen en verminderen. ${ }^{41}$ In dit kader dienen bedrijven ook inzicht te geven in de impact van hun activiteiten en plannen op omgevings- ('environment') en aan gezondheid gerelateerde rechten van kinderen. ${ }^{42} \mathrm{Om}$ dit te kunnen garanderen, dienen effectieve en transparante nationale procedures voorhanden te zijn om de relevante actoren verantwoordelijk te houden voor hun acties. ${ }^{43}$ Tot slot dienen lidstaten ook in het kader van klimaatverandering internationale samenwerking aan te moedigen (art. 24 lid 4). ${ }^{44}$

\section{Artikel 29 lid 1 onder e IVRK: respect voor de natuurlijke omgeving}

Artikel 29 lid 1 IVRK geeft aan dat de Staten die partij zijn bij het IVRK, het eens zijn over de onderwerpen waarop het onderwijs gericht moet zijn. De omschrij-

37. VN-Kinderrechtencomité (2019), Concluding observations on Australia, CRC/C/AUS/CO/5-6, par. 41.

38. VN-Kinderrechtencomité (2003), General comment No. 5 on General measures of implementation of the Convention on the Rights of the Child, CRC/GC/2003/5, par. 7.

39. VN-Kinderrechtencomité (2013), General Comment No. 15 on The right of the child to the enjoyment of the highest attainable standard of health (article 24), CRC/C/GC/15, par. 72.

40. Ibid, par. 48-49.

41. VN-Kinderrechtencomité (2013), General Comment No. 15 on The right of the child to the enjoyment of the highest attainable standard of health (article 24), CRC/C/GC/15, par. 76, 80.

42. VN-Kinderrechtencomité (2013), General Comment No. 16 on State obligations regarding the impact of the business sector on children's rights, CRC/C/GC/16; VN-Kinderrechtencomité (2019), Concluding observations on: Bosnia and Herzegovina, CRC/C/BIH/CO/5-6, par. 36; Singapore, CRC/C/SGP/CO/4-5, par. 16; Guinea, CRC/C/GIN/CO/3-6, par. 14

43. VN-Kinderrechtencomité (2013), General Comment No. 15 on The right of the child to the enjoyment of the highest attainable standard of health (article 24), CRC/C/GC/15, par. 92

44. Vgl. CESCR, General Comment No. 14 on the right to the highest attainable standard of health, E/C.12/2000/4, par. 39. 
ving van deze doelen van het onderwijs zijn tamelijk concreet. Zo dient bijvoorbeeld het onderwijs gericht te zijn op de zo volledig mogelijke ontplooiing van de persoonlijkheid, de talenten en geestelijke en lichamelijke vermogens van het kind, op het bijbrengen van eerbied voor de rechten van de mens, voor de ouders van het kind, de culturele identiteit, taal en waarden van het land waar het kind woont en ook op het bijbrengen van eerbied voor de natuurlijk omgeving.

Het VN-Kinderrechtencomité heeft in zijn eerste General Comment een nadere uitleg gegeven aan de doelen van het onderwijs die in artikel 29 lid 1 zijn opgenomen. ${ }^{45}$ Het VN-Kinderrechtencomité is van mening dat voor de ontwikkeling van respect voor de natuurlijke omgeving onderwijs een verband moet leggen tussen onderwerpen van 'environmental and sustainable development' en 'socio-economic, sociocultural and demographic issues'. Voorts merkt het Comité op dat kinderen respect voor de natuurlijke omgeving moet worden bijgebracht thuis, op school en in de lokale gemeenschap en dat dit zowel nationale als internationale problemen moet omvatten. Ook moeten kinderen actief betrokken worden bij lokale, regionale en globale projecten die betrekking hebben op de natuurlijke omgeving.

De Nederlandse regering heeft in 1992 bij de behandeling van de wet tot goedkeuring van het IVRK opgemerkt dat de toen bestaande onderwijswetgeving nakoming van artikel 29 lid 1 niet in de weg staat. Ook in de toekomstige wetgeving op het gebied van het primair of het voortgezet onderwijs zal rekening worden gehouden met de verdragsrechtelijke doelomschrijving van het onderwijs. ${ }^{46}$

Helaas moet 25 jaar na de inwerkingtreding van het IVRK in Nederland (op 8 maart 1995) worden geconstateerd dat het onderwijs met betrekking tot de rechten van het kind als erkend in het IVRK nog steeds geen vast onderdeel van het primair en voortgezet onderwijs vormt, ondanks herhaalde aanbevelingen van het Kinderrechtencomité om dat te doen. In 1999 het Comité 'urges the State party (....) to ensure that the Convention on the Rights of the Child and its provision are adequately covered in the existing curricula for older children and in new curricula for primary school pupils ${ }^{37}$ en in 2009 'make sure that child rights education is included in the school curricula at all levels' ${ }^{48}$ Of en, zo ja, op welke wijze kinderrechten aandacht krijgen in het onderwijs is derhalve nog steeds afhankelijk van de leiding van elke school afzonderlijk. Verschillende NGO's

45. General Comment No 1: The aims of education. UN Doc. CRC/GC/ 2001/1, 17 April 2001. Zie over de achtergrond van dit eerste General Comment het artikel van J.E. Doek in voetnoot 27, p. 16

46. Deze informatie is te vinden in de Memorie van Toelichting (MvT) op de Goedkeuringswet Tweede Kamer Vergaderjaar 1992/93, 22855 (R 1451), nr. 3. De tekst van deze MvT is o.a. te vinden in mr. Stan Meuwese e.a. (red.) Internationaal Jeugdrecht, p. 35-82. Nijmegen: Ars Aequi Libri 2005.

47. Concluding Observations Netherlands, UN Doc. CRC/C/15/Add.114 (26 October 1999), para 21.

48. Concluding Observations Netherlands, UN Doc. CRC/C/NLD/CO/3 (27 March 2009), para 62 (d). stimuleren een keuze voor kinderrechten onderwijs door lesmateriaal aan te bieden vooral voor het basisonderwijs $^{49}$.

Maar in dit zorgelijke plaatje vormt aandacht voor klimaat in het onderwijs een uitzondering. Een inventarisatie in 2012 leidde tot de conclusie dat in alle lagen van het onderwijs, van primair tot hoger onderwijs, aandacht is voor klimaatverandering. ${ }^{50}$ Voor het primair onderwijs is als leerdoel opgenomen dat kinderen moeten kunnen omschrijven hoe het weer en het klimaat in elkaar zitten. In het voortgezet onderwijs is klimaat(verandering) stevig verankerd in de eindtermen van het eindexamen aardrijkskunde. Er is ook een heel scala aan lesmateriaal ontwikkeld voor het primair onderwijs, zoals online klimaatgames, lesbrieven, lespakketten, excursies, filmpjes, opdrachten en handleidingen voor docenten, om zodoende het onderwijs te laten voldoen aan het bijbrengen van eerbied voor de natuurlijke omgeving zoals artikel 29, lid 1(e). Uit de beschikbare informatie blijkt niet dat een link wordt gelegd in het klimaatonderwijs met de rechten van het kind. Dit betekent dat het niet in de context van het IVRK wordt besproken. Bovendien legt het lesmateriaal niet het verband met 'socio-economic, socio-cultural and demographic issues' zoals het Comité wenselijk vindt. Het is van groot belang dat in het onderwijs aandacht wordt besteed aan de natuurlijke omgeving en dus ook aan klimaatverandering. Maar een belangrijk tekort is het ontbreken van de IVRK-context, waardoor bijvoorbeeld onvoldoende aandacht wordt besteed aan artikel 12. Ook buiten de school heeft het kind het recht betrokken te worden bij het opstellen en uitvoeren van maatregelen van de overheid die gevolgen (kunnen) hebben voor het klimaat.

\section{Artikel 6 IVRK: het recht op leven, overleven en ontwikkeling}

Artikel 6 IVRK bepaalt dat de verdragsstaten het recht van elk kind op leven erkennen en legt hen tevens de plicht op om het overleven en de ontwikkeling van het kind te waarborgen in de ruimst mogelijke mate. Het VN-Kinderrechtencomité plaatst deze drie onderdelen op een continuüm, waarbij het ene het andere versterkt. ${ }^{51}$ Het recht op leven is een inherent recht, zonder welke alle andere rechten in het IVRK betekenisloos zijn. Het recht op overleven verwijst hierbij naar minimumvereisten om de kindersterfte te verminderen en de levensduur van een kind te verlengen en is daarmee nauw gelinkt aan het recht op een adequate levensstandaard (art. 27 IVRK). ${ }^{52}$ Het Comité vraagt van lidstaten niet alleen om deze drie rechten te respecteren, maar ook om positieve actie, zoals het opzetten van bewust-

49. Lesmateriaal wordt aangeboden o.a. door het Kinderrechtencollectief, Kidsrights, Amnesty international, War Child en Terre des Hommes.

50. M. Pijnappels (2012), Inventarisatie klimaat educatie van primair tot hoger onderwijs, Alterra, Wageningen UR.

51. UNHRC, Legislative History of the Convention on the rights of the child, HR/PUB/07/1, New York \& Geneva: UN.

52. M. Nowak (2005), A Commentary on the United Nations Convention on the Rights of the Child, Article 6: The Right to Life, Survival and Development, Leiden: Martinus Nijhoff Publishers. 
makingscampagnes, passende wetgeving en het bestraffen van diegenen die het recht op leven, overleven of ontwikkeling direct of indirect schenden. ${ }^{53}$

Tegen deze achtergrond zou men verwachten dat dit een belangrijk recht is als het om klimaatverandering gaat. Desalniettemin zijn concrete aanbevelingen en interpretaties op dit vlak nog schaars. Artikel 6 IVRK is ook in andere contexten al genoemd als een vergeten recht dat het risico loopt een lege huls te worden bij een te brede interpretatie. ${ }^{54}$ Onder dit artikel valt namelijk veel te scharen. Desalniettemin kunnen de negatieve gevolgen van klimaatverandering moeilijk niet gelinkt worden aan het recht op leven, overleven en ontwikkeling, zoals ook het Comité zelf beaamt. ${ }^{55}$ Gebleken is verder dat het Comité onder andere een schone omgeving onder dit recht schaart. ${ }^{56}$ Daarnaast wordt in meerdere 'Concluding Observations' gewezen op de noodzaak om kinderen beter te informeren en voor te bereiden op natuurlijke rampen, hetgeen bijdraagt aan het recht op overleven en ontwikkeling en daarnaast ook het in artikel 29(1)(e) IVRK genoemde bijbrengen van eerbied voor de natuurlijke omgeving mogelijk een stap verder brengt. ${ }^{57}$ Zoals al vaker bepleit, verdient anbeveling dat het Comité in het vervolg meer zal ingaan op de precieze implicaties van artikel 6 in de klimaatcontext en dat het verdragsstaten hierop concreter zal bevragen en adviseren door middel van de 'Concluding Observations', opdat dit belangrijke recht niet daadwerkelijk een lege huls wordt. ${ }^{58}$

\section{Overige IVRK-rechten}

Andere belangrijke rechten zijn onder andere vervat in artikel 2 (non-discriminatie), 3 (belang van het kind), 12 (participatie), 23 (handicap), 27 (toereikende levensstandaard), 30 (minderheden) en 31 IVRK (spel), die door de gevolgen van klimaatverandering in meer of mindere mate aangetast kunnen worden of van belang zijn bij het nemen van maatregelen om die verandering aan te pakken. Daarnaast wordt in de 'Concluding Observations' meermaals verwezen naar de 'Paris Agreement' en de 'Sustainable Development Goals' die lidstaten onderschreven hebben. ${ }^{59}$ Tegen deze achtergrond dienen landen het Comité ook te voorzien van informatie over de gevolgen van klimaatverandering voor de bescherming van kinderrechten. ${ }^{60}$ Dat dataver-

53. Ibid.

54. J.E. Doek (2015), 'Article 6 CRC and the views of the CRC Committee', Stellenbosch Law Review, Vol. 26 No. 2, p. 254-271.

55. VN-Kinderrechtencomité (2019), Concluding observations on Australia, CRC/C/AUS/CO/5-6, par. 40.

56. M. Nowak (2005), A Commentary on the United Nations Convention on the Rights of the Child, Article 6: The Right to Life, Survival and Development, Leiden: Martinus Nijhoff Publishers.

57. VN-Kinderrechtencomité (2019), Concluding observations on: Cabo Verde, CRC/C/CPV/CO/2, par. 72, 73; Australia, CRC/C/AUS/CO/ 5-6, par. 40-41; Mozambique, CRC/C/MOZ/CO/3-4, par. 37; Tonga, CRC/C/TON/CO/1, par. 53-54; Japan, CRC/C/JPN/CO/4-5, par. 37.

58. Vgl. J.E. Doek (2015), 'Article 6 CRC and the views of the CRC Committee', Stellenbosch Law Review, Vol. 26 No. 2, p. 254-271.

59. Bijv. VN-Kinderrechtencomité (2019), Concluding observations on: Australia, CRC/C/AUS/CO/5-6; Japan, CRC/C/JPN/CO/4-5.

60. VN-Kinderrechtencomité (2019), Concluding observations on Cabo Verde, CRC/C/CPV/CO/2, par. 72-73. zameling nog veel verbetering behoeft, blijkt uit meerdere Concluding Observations. ${ }^{61}$ Voor een verdere verduidelijking van de verplichtingen van verdragsstaten is te hopen dat het Comité de huidige lijn doorzet, conform de aanbevelingen die tijdens de 'Day of General Discussion' in 2016 zijn gemaakt. ${ }^{62}$ Mogelijk ook dat de momenteel aanhangige zaak van Sacchi et al. t. Argentinië, Brazilië, Frankrijk, Duitsland en Turkije ${ }^{63}$ hieraan een eerste belangrijke bijdrage kan leveren (zie hierna).

\section{Kinderrechten in andere kaders}

Waar de juridische implicaties ten aanzien van het klimaat bij het IVRK nog in de kinderschoenen staan, zijn deze elders beter uitgekristalliseerd. Met name de Analytische Studie van de Mensenrechtenraad over klimaatverandering en kinderrechten uit 2017 is hierbij het vermelden waard. ${ }^{64}$ Niet alleen gaat deze in op de gevolgen van klimaatverandering voor kinderen, maar ook op de verplichtingen die staten op mensenrechtelijk vlak in dit kader hebben. Uitgangspunt hierbij is een op mensenen kinderrechten gebaseerde aanpak, zoals ook in diverse andere instrumenten wordt benadrukt. ${ }^{65}$ Dit houdt in dat bij de aanpak van klimaatverandering verplichtingen, ongelijkheden en kwetsbaarheden in kaart dienen te worden gebracht en discriminerende praktijken en onjuiste verdelingen van macht dienen te worden hersteld, terwijl rekening gehouden wordt met specifieke kenmerken van de rechten, behoeften en capaciteiten van kinderen. ${ }^{66}$ Hierbij ligt een sterke nadruk op rechtvaardigheid ('equity'). Dit veronderstelt dat de aanpak van klimaatproblematiek gezamenlijk dient te worden aangepakt en dat staten die de meeste schade veroorzaakt hebben niet alleen in meerdere mate moeten bijdragen aan de aanpak van klimaatverandering, maar ook landen die minder hebben bijgedragen moeten ondersteunen bij mitigatie en adaptatie. ${ }^{67}$ Ook vraagt het om actie van de huidige generatie om de negatieve effecten van klimaatverandering voor toekomstige generaties te minimaliseren ('intergenerational equity'). ${ }^{68}$

Meer concreet dienen staten urgente actie te ondernemen door de uitstoot van gassen te verminderen om zo sterk mogelijk negatieve mensenrechtelijke gevolgen op

61. K. Arts (2019), 'Children's Rights and Climate Change', in: C. FentonGlynn (ed), Children's Rights and Sustainable Development: Interpreting the UNCRC for Future Generations, Cambridge: Cambridge University Press, 2019, p. 228.

62. VN-Kinderrechtencomité (2016), Report of the 2016 Day of General Discussion: Children's Rights and the Environment, Genève.

63. Sacchi et al. (2019), Communication to the UNCRC, cases 104/2019 Argentina, 105/2019 Brazil, 106/2019 France, 107/2019 Germany and 108/2019 Turkey

64. UNHRC (2017), Analytical study on the relationship between climate change and the full and effective enjoyment of the rights of the child, A/HRC/35/13.

65. Zie bijv. The 2030 Agenda for Sustainable Development, the Paris Agreement en The Sendai Framework for Disaster Risk Reduction 2015-2030.

66. UNHRC (2017), Analytical study on the relationship between climate change and the full and effective enjoyment of the rights of the child, A/HRC/35/13, par. 31.

67. Ibid, par. 36

68. Ibid, par. 35 
kinderen en toekomstige generaties te voorkomen. ${ }^{69}$ Ook is het stopzetten van de ontwikkeling van de meest koolstof intensieve fossiele brandstoffen en de overgang naar schone, hernieuwbare energiebronnen vereist. ${ }^{70} \mathrm{Bij}$ de ontwikkeling van klimaatbeleid en -programma's dient voorop te staan dat mensenrechten worden vervuld, waarbij de risico's voor kinderen en wat in hun belang is in kaart wordt gebracht en participatie door kinderen wordt verzekerd. ${ }^{71}$ Ook hebben staten de plicht mensenrechten te beschermen tegen (klimaat)schade door bedrijven en hebben bedrijven tegelijkertijd de plicht geen schade aan te richten. ${ }^{72}$ Tot slot dienen voor dit alles effectieve en tijdige middelen voorhanden te zijn en dienen kinderen toegang te hebben tot informatie en onderricht te worden over de impact, risico's en gevaren van klimaatverandering. ${ }^{73}$

\section{Klimaatverandering en klachtrecht van kinderen}

Sinds 14 april 2014 kunnen kinderen als hun rechten, erkend in het IVRK, zijn geschonden een klacht daarover indienen bij het VN-Kinderrechtencomité. Die mogelijkheid bestaat op grond van het derde facultatieve Protocol bij het IVRK (hierna: OP-3), maar geldt alleen voor kinderen in een land dat dit protocol heeft geratificeerd. ${ }^{74}$

Hiervoor is uitgelegd welke rechten van kinderen door de klimaatverandering kunnen worden geschonden. Het was dan ook niet echt een verrassing dat op 23 september 2019 een groep kinderen een klacht hebben ingediend bij het Comité. De klacht is gericht tegen de regeringen van Argentinië, Brazilië, Frankrijk, Duitsland en Turkije. ${ }^{75}$ Kort samengevat houdt de klacht in dat deze regeringen niet voldoende hebben gedaan om te voldoen aan hun verplichting klimaatverandering en haar ingrijpende gevolgen, ook voor kinderen, te bestrijden en daardoor ook ernstig tekortgeschoten zijn in de bescherming van rechten van kinderen. Het beleid van deze regeringen leidt bovendien tot een schending van verschillende rechten van kinderen en het Comité wordt gevraagd bepaalde acties te ondernemen om deze schendingen een halt toe te roepen. Deze klacht heeft internationaal veel belangstelling gekregen en de indruk wordt gewekt dat het Comité niet veel anders te doen staat dan de klacht toe te wijzen en de gevraagde acties te ondernemen. Maar de behandeling van een klacht, ingediend

69. Ibid, par. 33.

70. Ibid, par. 33.

71. Ibid, par. 32

72. Ibid, par. 37

73. Ibid, par. 38-39.

74. Optional Protocol to the Convention on the Rights of the Child on a Communications Procedure, UN Doc./RES/66/138). Van de 196 Staten die partij zijn bij het Kinderrechtenverdrag, hebben tot nu (slechts) 46 het Protocol geratificeerd.

75. Het betreft de 'Communication to the Committee on the Rights of the Child', ingediend door zestien jongeren uit twaalf verschillende landen (Petitioners) op grond van het derde facultatieve protocol, is aan verschillende regels onderworpen. Hierna zal eerst aandacht worden besteed aan de vraag of de klacht ontvankelijk is, gevolgd door commentaar bij de gevraagde acties.

De klimaatklacht van 16 jongeren: ontvankelijk? Voor een goed begrip: het is een klacht tegen vijf regeringen, maar het Comité zal de klacht tegen elk van de regeringen apart moeten behandelen. ${ }^{76}$ Hier wordt volstaan met opmerkingen die voor alle klachten gelden. Er zijn verschillende voorwaarden waaraan moet zijn voldaan om de klacht inhoudelijk door het Comité te laten beoordelen. ${ }^{77}$ De klacht beperkt de bespreking van de ontvankelijkheid tot een van de voorwaarden: om ontvankelijk te zijn, moeten alle nationaal beschikbare rechtsmiddelen zijn aangewend voor de behandeling van de klacht. Maar deze regel wordt niet toegepast als kan worden aangetoond dat: a) de inschakeling van nationale rechtsmiddelen zal leiden tot een onredelijk langdurende procedure, en b) die rechtsmiddelen waarschijnlijk niet zullen leiden tot een effectieve hulp en/of steun voor de klager(s) (art. 7 onder (e) OP-3).

In de klacht wordt op deze voorwaarde uitvoerig ingegaan. Omdat duidelijk is dat de meeste van deze klagers geen procedures hebben gevoerd in de landen die worden aangeklaagd, ${ }^{78}$ worden vooral argumenten aangevoerd voor de toepassing van de uitzonderingen.

Het argument voor de eerste uitzondering: de rechtbanken van elk van de aangeklaagde landen zijn niet in staat om het gevraagde herstel te geven want het gaat om schendingen en schade op een wereldwijde schaal. Het instellen van nationaal gerechtelijke of andere acties in vijf verschillende landen heeft derhalve geen zin en is bovendien uitermate belastend en kostbaar.

Wat de tweede uitzondering betreft, wordt betoogd dat de procedures voor de gerechtelijke instanties in de vijf landen niet tot een effectief herstel kunnen leiden. Het gaat om juridische kwesties die ook te maken hebben met diplomatieke relaties en kwesties waarvan vaak verondersteld wordt dat ze zich niet lenen voor nationale gerechtelijke beslissingen. Ter illustratie: de Argentijnse jongere (Chiara Sacchi) kan volgens een traditionele opvatting van het internationaal recht niet de Argentijnse overheid aanspreken voor het niet gebruiken van diplomatieke middelen om haar te beschermen tegen CO2-uitstoot door de VS, omdat diplomatieke betrekkingen een op zichzelf staand rechtsgebied vormt. Dit

76. Derhalve is de klacht onderscheiden in vijf afzonderlijke klachten met een eigen nummer; no. 104/CO2 (Argentina), 105/2019 (Brazil), 106/2019 (France), 107/2019 (Germany) en 108/2019 (Turkey); zie website CRC Committee onder 'Table of Pending cases.

77. Art. 1 lid 3, 3 lid 2, 5 lid 2 en 7 OP-3; J.E. Doek, Communications with the Committee on the Rights of the Child under the Optional Protocol to the CRC on a Communications Procedure and Admissibility: Report on the Decisions of the Committee on Admissibility: Summary and Comments (Leiden Children's Rights Observatory Papers No. 1), 2020.

78. Een uitzondering is Ridhima Pandey, die in 2017 al een aanklacht tegen de Indiase overheid indiende bij India's National Green Tribunal. Zie 'Meet the 11-year-old- who sued the Indian government for inaction on climate change', https://scroll.in/article/940974/meet-the-11-yearold-who-sued-the-indian-government-over-climate-change. 
voorbeeld toont aan dat de klacht bij het Comité grensoverschrijdende schendingen van kinderrechten aan de orde wil stellen. Specifiek moet de nationale soevereiniteit volgens de aanklagers worden gezien als een juridische basis voor verantwoordelijkheid - bijvoorbeeld doordat de aangeklaagde staten bevoegd zijn om grote bedrijven in hun jurisdictie te reguleren - in plaats van als een begrenzing van deze verantwoordelijkheid. Deze benadering vraagt van het Comité dat het zijn bevoegdheid op een uitermate ruime manier interpreteert. OP-3 makkt duidelijk dat het Comité alleen afzonderlijke staten kan aanspreken op het niet nakomen van de verplichting om de rechten van alle kinderen onder hun jurisdictie te garanderen ( = 'to respect, protect and fulfil'). De vraag kan worden gesteld of het Comité een land kan aanspreken voor het nalaten van acties jegens een ander land dat niet voldoende doet tegen bijvoorbeeld $\mathrm{CO} 2$-uitstoot dat ook aan kinderen in andere landen schade berokkent. Hierbij moet opgemerkt worden dat het IVRK geen duidelijke grond biedt voor een veroordeling van een land, omdat het zich niet (voldoende) inzet voor internationale samenwerking omtrent klimaatverandering. Kortom, de eerste vraag voor het Comité zal zijn of het de klacht wel of niet ontvankelijk zal verklaren op grond van artikel 7(e) OP-3.

\section{De klacht inhoudelijk}

Indien het Comité de klacht wél ontvankelijk verklaart nog een opmerking over de aanbevelingen die het Comité volgens de klagers zou moeten nemen. In lijn met de benadering van de klagers wordt gevraagd om algemene conclusies. Bijvoorbeeld een van de bevindingen van het Comité zou moeten zijn dat de vijf aangeklaagde staten samen met andere staten de klimaatcrisis veroorzaken en daarmee doorgaan. Helaas wordt nergens aan het Comité gevraagd om vast te stellen dat bepaalde artikelen van het IVRK door de vijf Staten zijn geschonden en welke maatregelen zij zouden moet nemen om aan die schendingen een einde te maken. Wel wordt gevraagd dat het Comité de vijf Staten aanbeveelt om nationale en regionale wetten en beleid te herzien en waar nodig te amenderen om te verzekeren dat de inspanningen worden opgevoerd om de rechten van de klagers te beschermen en om het belang van het kind een eerste overweging te doen zijn in bijvoorbeeld het verdelen van de kosten en lasten van klimaatverandering.

Ten slotte, voor de kinderen die onder de Nederlandse jurisdictie vallen, bestaat helaas niet de mogelijkheid om bij het Kinderrechtencomité in Genève een klacht in te dienen over een schending van een recht dat zij op grond van het Kinderrechtenverdrag hebben. Dit is het gevolg van het feit dat de Nederlandse regering het OP-3 bij het IVRK nog niet heeft geratificeerd. Uiteraard kunnen deze kinderen wel in Nederland een klacht indienen bij een Nederlandse rechter als een van hun rechten wordt geschonden als gevolg van tekortkomingen in de aanpak van de klimaatverandering door de Nederlandse regering, en mogelijk met succes (zie de
Urgenda-zaak). ${ }^{79}$ Maar als een dergelijke actie geen succes heeft, kan geen klacht worden ingediend bij het Comité in Genève. Dat betekent dat deze kinderen niet de klachtmogelijkheid hebben die zij behoren te hebben. Kortom, een concrete actie in dit verband voor kinderen: samen met zo veel mogelijk andere personen en organisaties campagne voeren voor ratificatie door de Nederlandse regering van $\mathrm{OP}-3$.

\section{Tot besluit}

Met deze bijdrage hebben wij aandacht willen vragen voor de gevolgen die klimaatverandering kan hebben voor de verwezenlijking van de rechten van kinderen, zoals vastgelegd in het IVRK. Deze gevolgen hebben de afgelopen jaren steeds meer internationale aandacht gekregen, onder andere van de Algemene Vergadering van de VN, de Mensenrechtenraad en het VN-Kinderrechtencomité. Dit Comité heeft reeds aan veel landen concrete aanbevelingen gedaan voor de aanpak van klimaatverandering, waaruit blijkt dat de rechten van kinderen een belangrijke rol dienen te spelen bij het ontwerpen en uitvoeren van klimaatbeleid. Het is dan ook van groot belang dat de Nederlandse regering in de uitvoering van het Klimaatakkoord ernstig rekening houdt met de gevolgen van klimaatverandering voor de rechten van kinderen. Het IVRK biedt voor kinderen voldoende aanknopingspunten om in geval de regering in haar acties gericht op bestrijding van klimaatverandering ernstig tekortschiet in het beschermen van hun rechten, een klacht in te dienen bij een rechter in Nederland. Bovendien hebben kinderen het voordeel dat zij zich hierbij kunnen beroepen op één alomvattend verdrag, te weten het IVRK, in tegenstelling tot volwassenen, voor wie (klimaatgerelateerde) mensenrechten verspreid zijn over meerdere verdragen en documenten. Maar de mogelijkheid om die klacht zo nodig ook bij het Kinderrechtencomité aan de orde te stellen, hebben kinderen helaas niet. Om aan die beperking een einde te maken, verdient het aanbeveling dat de Nederlandse regering het OP-3 - al bijna tien jaar geleden door de Algemene Vergadering van de VN goedgekeurd - gaat ratificeren, zodat ook alle kinderen in Nederland de mogelijkheid hebben om hun klacht over de schending van een recht aan de hoogst bevoegde internationale instantie voor te leggen. 